\title{
EFFECTIVE BASEMETAL HEDGING: THE OPTIMAL HEDGE RATIO AND HEDGING HORIZON
}

\author{
Michaël Dewally \\ Marquette University \\ Luke Marriott \\ MillerCoors
}

\begin{abstract}
This study investigates optimal hedge ratios in all base metal markets. Using recent hedging computation techniques, we find that 1) the short-run optimal hedging ratio is increasing in hedging horizon, 2) that the long-term horizon limit to the optimal hedging ratio is not converging to one but is slightly higher for most of these markets, and 3) that hedging effectiveness is also increasing in hedging horizon. When hedging with futures in these markets, one should hedge long-term at about 6 to 8 weeks with a slightly greater than one hedge ratio. These results are of interest to many purchasing departments and other commodity hedgers.
\end{abstract}




\section{INTRODUCTION}

Hedging is considered an integral part of a competitive and successful commodity purchasing department. With raw material demand rising globally the strategic importance of hedging has never been as critical as it is today. Volatility in commodity markets continues to increase because of 1) political uncertainty and natural disasters, 2) the expanding global nature of trade and the resulting soaring demands from remote markets, and 3) a corresponding shift in manufacturing capacity as more product flow into the U.S. from abroad (Dickson et al. (2006)). Due to the increased volatility in commodity markets and strengthened global competition, companies can no longer rely on traditional approaches, such as strategic sourcing and volume aggregation, to manage their purchasing needs. Multinational firms no longer compete "...by exploiting scale and scope economies or by taking advantage of imperfections in the world's goods, labor, and capital markets" (Hansen and Nohria (2004)). Firms must rely more than before on risk management techniques to manage their materials exposure. These techniques include, but are not limited to, eliminating cost inefficiencies in operations, hedging commodity price risk with financial derivatives, and altering hedging horizons.

Our study concentrates on optimal hedging ratios and horizons in the metals markets. Our results show that 1) the short-run optimal hedging ratio is increasing in hedging horizon, 2) the long-term horizon limit to the optimal hedging ratio is not converging to one but is slightly higher for most of these markets, and 3) hedging effectiveness is also increasing in hedging horizon. The best hedging decision for these markets is to hedge long-term at about 6 to 8 weeks with a slightly greater than one hedge 
ratio. These findings provide insights and a better understanding of the characteristics and properties that shape the effectiveness of futures commodity trading, insights that are valuable and relevant to the general commodity hedger.

In 2003, a survey taken as part of the Corporate Executive Board Procurement Strategy Council (2003) revealed that $41 \%$ of risk managers believe that their procurement department will become significantly more important in the coming years and, critically, over $50 \%$ acknowledge that the effectiveness of their procurement organization's risk management division needs significant improvement. In fact, these managers ranked commodity price risk as more relevant than currency price risk by a 3 to 2 ratio. Consequently, it is no surprise that hedging demand in the metals markets is such that, over the period from Jan-June 2005 to Jan-June 2006, non-precious metals futures trading increased by $21 \%$ in volume and the volume for aluminum contracts alone increased by $32 \%$ (Holz (2006)). Wall Street is responding to the demand by hiring more traders and new product developers. Barclays aims to hire $20 \%$ more staff in 2007 after it already increased staff by $35 \%$ the previous year (Freed (2007)). Market demand projections see no end to this trend. In the aluminum market, demand is projected to grow by $9.4 \%$ in 2007 , following on the $20068 \%$ growth. This matches unfavorably with the projections in supply. The International Primary Aluminum Institute forecasts an increase in production in 2007 of $6.5 \%$ and an increase in 2008 of $3.4 \%$. While metals producers can expect profitable years, metal consumers are faced with difficult choices and reduced profitability. Market conditions point to the need for a concerted risk management policy at the corporate level. 
The hedging literature is vast and covers both the motives for hedging and the strategies used to address these motives. For the current study, it is important to recall two areas of the literature. First, one branch of the literature aims to justify the use of hedging by procurement divisions (Froot et al (1993), Hansen and Nohria (2004), Koppenhaver and Swidler (1996)), while the second helps determine how best to select optimal futures positions that minimize the risk inherent in the spot (cash) market (chronologically, Fletcher and Ward (1971), Benninga et al (1984), Perron (1989), Baillie and Meyers (1990), Chowdhury (1991), Lien and Luo (1993), Geppert (1995), Alexander (1999), Chen, Lee and Shrestha (2004)). This study is an investigation into the optimal hedge ratio and hedging effectiveness for base metals.

Hedging in futures markets involves taking a futures position opposite to that of a spot market position (Institute for Financial Markets (1998)). For commodity purchasing departments, the futures markets effectively represent a pricing mechanism in the commodity purchasing process. One common definition of the optimal hedge ratio is "...the ratio of the covariance between spot and futures prices to the variance of the futures price" (Myers and Thompson (1989)). Intuitively, the optimal hedge ratio defines the futures market position that will simultaneously minimize the risk absorbed in the spot market or, plainly, what amount of the commodity should be hedged with futures. We also look specifically at the hedging horizon, as previously studied by Chen, Lee, and Shrestha (CLS) (2004) using cointegration to estimate the optimal hedge ratio, to determine whether hedging effectiveness improves across greater hedging time horizons. 
This study analyzes the six base metals traded on the London Metal Exchange (LME): aluminum, copper, lead, nickel, tin, and zinc. The use of LME base metals is beneficial given its global acceptance as the world's leader in metal futures trading. It is also interesting to study these futures and their respective hedging effectiveness given their dramatic upswing in volatility over the past few years: the six base metals volatilities increased by $174 \%$ on average.

The paper first presents a review of the academic literature then Section III presents the empirical questions. In Section IV, we present the data and the methodology. Section V reports the results and we conclude in Section VI.

\section{LITERATUTE REVIEW}

Our study builds on the last 25 years of the optimal hedge ratio literature. Our empirical models for estimation are based on the body of research that started with Ederington in 1979. This research area evolved through three phases. First and notably, Ederington (1979) established the first empirical models; later more sophisticated techniques of GARCH estimation were applied, and most recently approaches of cointegration have been used.

Ederington (1979) is the first to empirically estimate optimal hedge ratios and is accordingly credited with formulating the theoretical framework. Ederington summarizes the three working theories of hedging at the time: 1) Traditional Theory, 2) Theories of Holbrook Working, and 3) the Portfolio Theory. He finds fault with Traditional Theory, 
the leading theory at the time. Ederington challenges its convenient yet unrealistic assumption that a change in futures price is exactly proportionate to a change in cash prices. Ederington argues that the theories of Holbrook Working improve on the inherent weakness of the Traditional Theory by bringing light to the fact that most hedgers do account for the dynamic information the cash-futures basis provides at the time the hedge is placed. Still, the study argues that a more realistic approach is to view hedging in a risk and return framework best formulated by an approach that combines Portfolio Theory and Working's Theory. This provides rationale as to why a hedger may at different times be either hedged or completely un-hedged.

Ederington's seminal contribution to the optimal hedge ratio literature is the empirical finding that even pure risk minimizers will hedge less than their spot market requirements which is contrary to the findings of preceding research. Moreover, he finds that hedging effectiveness improves across two time horizons for financial security futures. Specifically, his findings show that the futures markets for two financial securities prove to be more effective hedging instruments over longer periods. However, the limitation of only using two time horizons, along with the arbitrary method of defining a long period as four weeks and a short period as one week, jeopardizes the applicability of Ederington's conclusions. Furthermore, the study assumes that the minimum variance hedge ratio is simultaneously the optimal hedge ratio without formally proving or interpreting this relationship. A second related weakness lies in the assumption that a hedger who maximizes profit will simultaneously be minimizing the variance of the hedge. 
In consideration of these limitations, several important studies quickly addressed these concerns. Benninga, Eldor, and Zilcha (1984) respond first, finding fault in the latter of the two weaknesses. Benninga et al. (1984) find that assuming a hedger has a quadratic utility function presents 'undesirable properties' for estimation and also point out that the assumption that the minimization of producer income variance is equivalent to the optimal hedge ratio is theoretically inappropriate. Instead, Benninga et al. do prove that, in unbiased futures markets, the minimization of income variance is equivalent to the optimal hedge ratio.

Benninga et al. make two assumptions: 1) the futures price is an unbiased predictor of the future spot price, $\left[\mathbf{F}_{\mathbf{0}}=\mathbf{E}_{\mathbf{0}}\left(\mathbf{F}_{\mathbf{1}}\right)=\mathbf{E}_{\mathbf{0}}\left(\mathbf{P}_{2}\right)\right]$, and 2) the regressibility of spot prices on futures price, $\left[\mathbf{P}_{\mathbf{1}}=\boldsymbol{\alpha}+\boldsymbol{\beta F}_{\mathbf{1}}+\varepsilon\right]$ where $\varepsilon$ is homoscedastic. $\mathbf{F}_{\mathbf{0}}$ represents the futures price at $\mathrm{t}=0, \mathbf{F}_{1}$ represents the futures price at $\mathrm{t}=1$, and $\mathbf{P}_{\mathbf{2}}$ represents the spot price at $\mathrm{t}=2$. Therefore, both $\mathbf{F}_{\mathbf{1}}$ and $\mathbf{P}_{\mathbf{2}}$ are unknown prices that the producer faces in everyday hedging decisions. In unbiased markets, the only reason for the producer to hedge is to minimize risk, given that on average there will be little to gain in an unbiased market. Therefore, the optimal hedge is where $\mathbf{X}=\boldsymbol{\beta} \mathbf{Q}$ with $\mathbf{Q}$ representing the quantity required in the spot market and $\mathbf{X}$ representing the optimal amount hedged on the futures market. Assumption 2 may be econometrically troublesome since the use of price levels can lead to autocorrelation with the residuals. Therefore, using price changes, $\left[\left(\mathbf{P}_{\mathbf{1}}-\mathbf{P}_{\mathbf{0}}\right)=\boldsymbol{\alpha}+\right.$ $\left.\boldsymbol{\beta}\left(\mathbf{F}_{1}-\mathbf{F}_{\mathbf{0}}\right)+\varepsilon\right]$ rids the model of autocorrelation. This model still yields the optimal hedge ratio under the assumption of unbiased futures markets. The only uncertainty remaining in the producer's expected income is the residual and the regression coefficient, $\boldsymbol{\beta}$, is the 
minimum variance hedge ratio. The strength of their results "...derives from its generality (it is free from assumptions about utility functions) and from the ease of its applicability (it requires only a regression analysis to derive the optimal hedge ratio)" (Benninga et al (1984)).

Following the research by Benninga et al (1984), the empirical estimation of the optimal hedge ratio was improved by accounting for cointegration between spot and futures prices. One of the key findings is that spot and futures prices tend to drift together over time. Chowdhury (1991) proves that “...the market efficiency hypothesis requires that the current futures price and the future spot price of a commodity are close together." This follows from the definition of market efficiency which implies that current prices should reflect all current and past price information in establishing current market prices. Chowdhury uses price data from the LME to test the hypothesis of market efficiency (cointegration) for copper, lead, tin, and zinc. ${ }^{1}$ Cointegration is found between the four base metals studied suggesting that the use of conventional estimation techniques to estimate the optimal hedge ratio would lead to over-hedging. A model that fails to incorporate the long run co-movement between variables does not capture the mean reverting tendency of the model, which leads to an upward bias in the point estimates in the model.

\footnotetext{
${ }^{1}$ Base metals are some of the most commonly traded futures contracts, yet this is the only study to incorporate base metals in the optimal hedge ratio analysis. It should be noted that the Chowdhury study does not give any attention to hedging strategy, paying all of its attention to the statistical properties of cointegration.
} 
Lien and Luo (1993) address the problem of over-hedging by estimating the optimal hedge ratio using an error correction model to account for the issue of cointegration the Chowdhury study raises. Lien and Luo run their estimation at 9 hedging horizons and find that the optimal hedge ratio tends to fluctuate before converging towards one suggesting that the optimal hedge ratio converges to the naïve hedge ratio over time. These findings were later augmented by Geppert (1995), who establishes that hedging effectiveness and the optimal hedge ratio both depend on the permanent and transitory components of the price changes between spot and futures prices. "Over long horizons, the shared component ties the spot and futures series together and the two prices will be perfectly correlated" (Geppert (1995)). A major weakness in the Geppert study is the model requirement that both spot and futures prices be I(1) to implement the Stock and Watson (1988) methodology suggested in the study. It would be useful to adopt a methodology that provides valid hedge ratios when the unitroot condition is not satisfied.

Such a study is Chen, Lee and Shrestha (CLS) (2004). CLS empirically estimate the optimal hedge ratio with a cointegration methodology that does not require both the spot and futures prices to contain a single unit root. They are able to estimate both the short-run and long-run hedge ratios with the Pesaran et al (2001) approach that does not require both series to be $\mathrm{I}(1)$ or $\mathrm{I}(2)$ together. This approach works when prices are unit root processes and when they are stationary. In all, 9 different hedging horizons are considered over 25 different commodities. As expected, they find that the futures and spot prices share a stochastic trend implied theoretically by market efficiency and the noarbitrage condition. In estimating the optimal hedge ratios they find that hedging 
effectiveness does improve over greater hedging horizons and that the short-run hedge ratio is significantly less than one. Our study of the six LME metals follows the CLS methodology.

\section{EMPIRICAL QUESTIONS}

In principle, futures markets exist to offer buyers and sellers of the underlying commodities, financial instruments, or index the opportunity to minimize the price risk inherent in cash market positions. These open markets allow for better price discovery. Moreover, futures markets are appealing to firms because of high liquidity and ease of entry/exit properties. Various businesses across the globe utilize these advantageous properties to manage price risk exposure. This translates to firm cost savings as they mitigate their risk exposure. Firms especially adept at risk management will likely survive periods of high price risk and volatility. Given the recent competitive nature of the commodity landscape, firms are implementing and plan to implement multitudes of hedging strategies to trim the costs of elevated commodity prices.

In commodity purchases, hedging using futures contracts can be thought of as offsetting the risk imposed by a firm's commodity requirements. A firm that requires a fixed amount of copper in the production of their good would want to offset their market price risk by buying copper futures against their annual requirements. Under a futures contract, the price is set for delivery at a future date. Therefore, if the trader is anticipating a bullish copper market, she would be wise to assume a long position defined 
as buying deferred month futures contracts. This allows the trader to realize this gain in futures prices which would alleviate the upside price risk in the spot market.

Hedging price risk involves not only when to be short and when to be long but it also requires a thorough understanding of the long-run relationship between the spot and futures markets. This may be the most important element in an efficient commodity purchasing department because it ultimately reveals how effective a department is at using the price discovery relationship in formulating hedging strategies. The price discovery relationship implies that spot and futures share a long-run stochastic trend; thus, an effective hedging department would understand that over longer hedging horizons prices tend to revert to the mean together. For these reasons, the hedging horizon is the key issue being addressed in this research. Given the volatile and upward trending data employed in this study, it seems appropriate to hypothesize that the hedging effectiveness of a firm with a comparatively longer hedging horizon would be much more effective in minimizing risk over our data period. The current research consensus is that spot and futures markets move together over long horizons. This implies that a firm facing adverse upside price risk would be wise in lengthening their hedging horizon to offset the unfavorable prospect of increasing spot market prices.

Let us look at a trading scenario in the aluminum futures market to emphasize the importance of effective risk management. Consider major American beverage industry players such as Pepsi-Cola Co., Anheuser-Busch Inc., Miller Brewing Co., and CocaCola Co. All of these firms have significant annual aluminum requirements. Correspondingly, all these companies assume a long position in the futures markets 
because they are always in demand of (buying) aluminum to package their respective products. Aluminum has recently experienced a $41 \%$ increase in its mean historical futures price. Likewise, the spot market prices followed this trend but in an often erratic and unpredictable fashion. This naturally introduced a considerable amount of basis risk, making the hedging decisions by commodity traders within these companies difficult at best. Basis risk is the unexpected fluctuations in the prices of cash and futures that is a product of influences ranging from seasonality to supply disruptions. All of these firms likely would have endured this period unsuccessfully without the use of some form of hedging strategy.

Consider a beverage company, similar to one of the firms mentioned above, with an annual and realistic aluminum requirement of 100,000 metric tons (MT). The standard aluminum contract is specified for $25 \mathrm{MT}$ at some point in time for future delivery. Now, consider the price of $\$ 1,322$ for cash aluminum in October of 1998 and compare it to the prices prevailing in May of 2000.

\section{$\underline{\text { Actual Aluminum Market Timeline }}$}

\begin{tabular}{|l|}
\hline October 1998 \\
Price: $\$ 1,322$
\end{tabular}

May 2000

Price: $\$ 1,498$

$\underline{\text { Actual Aluminum Market Time Spread }}$

October 1998

Price: $\$ 1,322$

$\$ 1,357$ 
The market in October was in contango as indicated by the futures price being greater than that of the market. Therefore, pursuing the recommended strategy above would lead to hedging the spot market position of 100,000 MT. This strategy would lock in the price of $\$ 1,357 / \mathrm{MT}$ on October of 1998 for delivery in May 2000. Assuming away transaction costs, this simple hedging strategy would save the hypothetical firm $\$ 14 \mathrm{M}$ dollars $(=(1,498-1,357) * 100,000)$. The questions a commodity hedger has to answer before implementing her strategies include: what is the best hedge ratio and what is the best time horizon for this hedge? Our methodology allows us to answer these two questions.

\section{ECONOMETRIC METHODOLOGY}

Table 1 shows the six metals markets our data set covers. All these metals are traded on the London Metal Exchange: Aluminum, Copper, Lead, Nickel, Tin, and Zinc. Our dataset is longer than those in previous studies and provides the daily close price for both the cash and futures prices dating back to July of 1998 and up to October 2006. The futures data is collected from Futuresource, a database specifically designed for commodity traders. The futures price data represent the near-by futures contract or the contract with the closest settlement date and rolled over 10 days prior to expiration. Cash prices used are very closely related to the second bell close on the LME, since nearly all metals pricing is based on this quote.

[INSERT TABLE 1 HERE] 
Table 2 illustrates the recent increased volatility in the metal markets: the price standard deviation increased across the six metals by an average of $174 \%$. The table also reports the ratio of the standard deviation to the mean price to indicate how volatility increased in proportion to the average price for all six of the base metals. This statistic indicates that both mean prices and standard deviation increased over the period. Figure 1 illustrates the increased volatility prevailing in the current commodity landscape. The figure shows the dramatic upward shift in prices that has occurred in all six of the contacts over the last two years of our sample. We observe that mean aluminum futures prices increase over $41 \%$ after the break point in March 2005, with a record high being reached on May 11, 2006. Copper provides a similar story, but the mean futures prices more than doubles (137\%) with a record high also being reached on May 11. The copper contract is usually regarded as the leading base metal, primarily because of its large trading volume, which helps explain the contract's significant uptrend in comparison to aluminum, lead, nickel, and tin. Finally, Panel A illustrates the increase of futures prices in the zinc market of over $100 \%$. Lead's historical prices reached a record high on October 16 and the mean futures price increasing over 77\%. Nickel's price path parallels that of copper with its price more than doubling (124\%). Again, the record high was established on October 16. Tin increases modestly in comparison to Lead and Nickel with a much less dramatic increase of 51\% with a record high being set on October 16 .

[INSERT FIGURE 1 HERE]

[INSERT TABLE 2 HERE] 
Empirically, the estimation follows the derivation provided by Benninga et al. (1984). First, let's assume that a commodity purchasing department for a beverage company has to buy some quantity $(\mathrm{Q})$ of aluminum at $\mathrm{t}=1$. The price $\left(\mathrm{P}_{1}\right)$ at period $\mathrm{t}=1$ is uncertain since one is unable to predict future prices. The commodity trader can purchase futures $\left(\mathrm{F}_{0}\right)$ at $\mathrm{t}=0$ to offset the uncertainty of the price $\left(\mathrm{P}_{1}\right)$ at $\mathrm{t}=1$. The income of the firm after implementing the hedge is, therefore, represented in equation (1) below,

$$
\mathrm{QP}_{1}+\mathrm{X}\left(\mathrm{F}_{0}-\mathrm{F}_{1}\right)(1)
$$

where $F_{1}$ represents the futures price at $t=1$ and $X$ represents the trader's hedge. In this case, the quantity $X$ represents a long position in the futures market and the difference in the two futures prices will establish whether the hedge was favorable.

In order to derive the optimal hedge ratio, one must assume that the futures market is an unbiased predictor (market efficiency) of the spot market which is denoted below in equation (2). This assumption is not unrealistic given the wide body of research on cointegration that indicates that futures and spot prices do share a mean-reverting relationship in the long run (Lien and Luo (1993), Geppert (1995), Alexander (1999), CLS (2004)). It is also assumed that the spot price shares a linear relationship with the futures market or that spot prices can be regressed on futures prices. This holds if $\varepsilon$, the error term, is not correlated with $\mathrm{F}_{1}$ (Benninga et al (1984)).

$$
\begin{gathered}
\mathrm{F}_{0}=\mathrm{E}_{0}\left(\mathrm{~F}_{1}\right)=\mathrm{E}_{0}\left(\mathrm{P}_{2}\right)(2) \\
\mathrm{P}_{1}=\alpha+\beta \mathrm{F}_{1}+\varepsilon(3)
\end{gathered}
$$


Subsequently, the variables are differenced to rid the model of this inherent problem as illustrated below in equation (4). All the assumptions still hold if equation (4) is estimated in favor of equation (3).

$$
\left(\mathrm{P}_{1}-\mathrm{P}_{0}\right)=\alpha+\beta\left(\mathrm{F}_{1}-\mathrm{F}_{0}\right)+\varepsilon(4)
$$

Equation (5) replicates equation (1) but in this case the dependent variable is included to capture the income of the firm after the hedge is completed.

$$
\mathrm{I}=\mathrm{QP}_{1}+\mathrm{X}^{*}\left(\mathrm{~F}_{0}-\mathrm{F}_{1}\right)(5)
$$

The expected income of the firm is found to equal the cost of the spot market requirement under the unbiasedness assumption in equation (2). This relationship is denoted below in equation (6), where the two futures prices cancel out under the assumption of unbiasedness. The only reason remaining to hedge is to minimize the risk that the commodity poses.

$$
\mathrm{E}_{0}(\mathrm{I})=\mathrm{Q} * \mathrm{E}_{0}\left(\mathrm{P}_{1}\right)+\mathrm{X}^{*}\left(\mathrm{~F}_{0}-\mathrm{E}_{0}\left(\mathrm{~F}_{1}\right)\right)=\mathrm{Q}^{*} \mathrm{E}_{0}\left(\mathrm{P}_{1}\right)(6)
$$

If the commodity trader allows his hedge position to equal the product of the coefficient in the regression equation $(\beta)$ with the physical requirement of the commodity (Q) then equation (7) below follows. This is the result of substituting ( $\beta * \mathrm{Q})$ for $\mathrm{X}$ in equation (5).

$$
I=Q\left(P_{1}-\beta F_{1}\right)+Q \beta F_{0}(7)
$$

Solving equation (3) for $\left(\mathrm{P}_{1}-\beta \mathrm{F}_{1}\right)$ allows the substitution of $(\alpha+\varepsilon)$ into equation (8) below:

$$
\mathrm{I}=\mathrm{Q}(\alpha+\varepsilon)+\mathrm{Q} \beta \mathrm{F}_{0}(8)
$$


Equation (8) proves that the optimal hedge ratio is $X=(Q \beta)$ and it indicates that the only remaining uncertainty in the equation is in the error term which, by definition, cannot be hedged. Therefore, all income variance is eliminated and the only reason for the trader to hedge is to minimize the risk variance captured by $(\mathrm{Q} \beta)$. This finding proves that the minimum variance hedge ratio is also the optimal hedge ratio.

Equation (9) represents the minimum variance hedge ratio defined by Ederington (1979) when the trader/producer is attempting to minimize income variance.

$$
\operatorname{Var} I=Q^{2} \operatorname{Var} P_{1}+X^{2} \operatorname{Var} F_{1}-2 Q X \operatorname{Cov}\left(P_{1}, F_{1}\right)(9)
$$

The minimum variance hedge can also be represented as equation (10) below with the use of simple differentiation:

$$
\mathrm{X}=\mathrm{Q} \operatorname{Cov}\left(\mathrm{P}_{1}, \mathrm{~F}_{1}\right) / \operatorname{Var} \mathrm{F}_{1}(10)
$$

Note that $\mathrm{X} / \mathrm{Q}$ is equivalent to $\beta$, the coefficient representing the hedge ratio in equation (4), which is also equivalent to the expression $\operatorname{Cov}\left(\mathrm{P}_{1}, \mathrm{~F}_{1}\right) / \mathrm{Var} \mathrm{F}_{1}$.

Given this proof, it is theoretically valid to empirically estimate the optimal hedge ratio with the differenced form equation (4) above. Before estimating this model, it needs to be addressed how the optimal hedge ratio will be estimated for the different hedging horizons. These estimation techniques are produced in the studies by Geppert (1995) and CLS (2004). Both studies prove that the price changes $\left(\Delta \mathrm{P}_{\mathrm{t}}\right.$ and $\left.\Delta \mathrm{F}_{\mathrm{t}}\right)$ in equation (4) should be k-period differenced to properly estimate a respective k-period hedging horizon optimal hedge ratio. Simply put, this means that the frequency of the data must match the hedging horizon of the estimated optimal hedge ratio. A major drawback in the Geppert study is the use of overlapping differencing to prevent the sample size from becoming too 
small. As CLS points out, such a method produces correlated observations which lead to a regression that has autocorrelated error terms. This should be avoided to eliminate the upward bias in estimates of the statistical significance of coefficient estimates. The sample size in the present study is large enough to warrant the use of non-overlapping differences which prevents the troublesome properties of autocorrelated error terms produced by overlapping differencing.

The next step in the methodology is to test for unit root in the prices for both the spot and futures in all six of the base metals. This is necessary because, as market efficiency implies, futures and spot prices should move together over time. Under market efficiency, if the futures move in one direction then so do the spot prices, implying that if both series are I(1) then they also should be cointegrated. Perron (1989) unit root tests are performed to account for the breaks in the data that are quite obvious when visually examining Figures 1-6. This method tests for stationarity after detrending the series and allowing for structural breaks. The structural breaks in this test should be exogenous. This is easily supported in the base metals as speculative hedge funds have increasingly emerged in commodity markets to create more balanced portfolios. This phenomenon has coincided with the price increases outlined in Figures 1-6 and would be difficult to conceive as anything but exogenous in the causality of futures prices. Detrending the series using both slope and intercept shifts are employed after several updates to the study have shown this method to be preferred (Pesaran (1997)). Choosing the break points for these tests is done by visually examining the data to determine the break in the data which is used in estimating the test statistic. 
After the unit root tests are performed, it is necessary to evaluate whether cointegration exists among the prices of both the futures and spot markets. Again, market efficiency implies that this is the case. CLS only assumes cointegration so this study improves upon this by empirically verifying the long-run co-movement. Cointegration is tested using the Pesaran et al method (2001) which transforms equation (4) into the unconstrained version of the error-correction model denoted by equation (11) below:

$$
\Delta \mathrm{P}_{\mathrm{t}}=\alpha-\beta_{1} \Delta \mathrm{F}_{\mathrm{t}-1}-\beta_{2} \Delta \mathrm{F}_{\mathrm{t}-2}+\beta_{3} \Delta \mathrm{P}_{\mathrm{t}-1}+\beta_{4} \Delta \mathrm{P}_{\mathrm{t}-2}+\Phi_{1} \mathrm{~F}_{\mathrm{t}-1}+\Phi_{2} \mathrm{P}_{\mathrm{t}-1}+\varepsilon_{\mathrm{t}}(11)
$$

In (11), two lags are included for the purpose of uniformity but in the actual estimation of the test, lags will be determined with the Akaike Information Criterion (AIC) model selection test. The Pesaran approach uses an F-statistic to test whether the lagged level variables are jointly significant $\left[\Phi_{1}=\Phi_{2}=0\right]$. Critical values for these tests are obtained from the study by Pesaran et al (2001). These tests are performed with the weekly data that are also used in the unit root tests.

After testing for cointegration, the simultaneous equation models considered by Pesaran (1997) in equation (8) of that study is adapted to jointly estimate the ratios, which allow us to evaluate the long-run relationship that exists between spot and futures prices enabling a dynamic model that corrects short-run deviations from the long-run equilibrium (Alexander (1999). Equation (12) is "...parameterized so as to be closely associated with the error-correction models encountered in the vector autoregressive models with cointegration" CLS (2004):

$$
\left(\mathrm{P}_{1}-\mathrm{P}_{0}\right)=\alpha_{1}+\alpha_{2} \mathrm{P}_{\mathrm{t}-1}+\alpha_{3} \mathrm{~F}_{\mathrm{t}-1}+\beta\left(\mathrm{F}_{1}-\mathrm{F}_{0}\right)+\varepsilon(12)
$$


This equation differs from the error correction model in that $\Delta \mathrm{F}_{\mathrm{t}}$ is used instead of the $\Delta \mathrm{F}_{\mathrm{t}-1}$ term that the vector autoregressive model yields. This alteration is supported theoretically in the CLS study which uses $\Delta \mathrm{F}_{\mathrm{t}}$ because it explicitly represents the shortrun hedge ratio. Additionally, a simultaneous equations approach is avoided because the interest lies only in the short-run and long-run ratios. In equation (12) both the short-run and long-run hedge ratios can be estimated where $-\alpha_{3} / \alpha_{2}$ is the long-run hedge ratio, as proved by Geppert, and $\beta$ is the short-run hedge ratio. This eliminates the problem associated with equation (4) only incorporating short-run information. It is anticipated that the long-run hedge ratio will remain constant and that the short-run ratio will converge to the long-run ratio across greater time horizons. Equation (12) is supported theoretically by CLS and adapted from Pesaran et al.

The final and most important step in the methodology involves testing the out-ofsample hedging effectiveness. Out-of-sample hedging effectiveness will enable the researcher to evaluate how effective the hedging strategy is over increasing hedging horizons. Using equation (13) as the hedged portfolio, hedging effectiveness will be determined by equation (14) which frequently serves as a measure of hedging effectiveness in the body of research on optimal hedge estimation (see among others, Anderson and Danthine (1981) or Meyers and Thompson (1989)):

$$
\begin{gathered}
\Delta \mathrm{V}_{\mathrm{h}}=\mathrm{Q}\left(\Delta \mathrm{P}_{\mathrm{t}}\right)+\mathrm{X}\left(\Delta \mathrm{F}_{\mathrm{t}}\right)(13) \\
1-\left[\operatorname{Var}\left(\Delta \mathrm{V}_{\mathrm{h}}\right) / \operatorname{Var}\left(\Delta \mathrm{P}_{\mathrm{t}}\right)\right](14)
\end{gathered}
$$

The first half of the sample will be utilized to compute the optimal hedge ratio across all of the hedging horizons with these estimated hedge ratios being substituted for 
$\mathrm{X}$ in equation (13). Furthermore, the second half of the data set will be used in calculating the remainder of the coefficients with Q being set to 1. Ultimately, this equation represents the amount of variance reduced with the implementation of the hedge above and beyond that of an unhedged position.

\section{RESULTS}

The first part of the methodology involves testing for unit root or the stationarity of the variables. Table 3 shows the results of the unit root tests conducted on the weekly data for each market. All the variables except for the futures prices on zinc appear to be I(1) or integrated of order 1 . The $\lambda$ represents the proportion of the sample at which the break point occurs, measured from the beginning of the data sample to the breaks, which are determined visually. ${ }^{2}$ The finding on zinc might be attributed to the low power of unit root tests. In any case, the test statistic is close to passing the test and would hypothetically pass at the $12 \%$ level of significance. The DF-GLS test was also used to provide further insight into the results, and the finding from this test shows that zinc does in fact have unit root. These findings coupled together point to zinc futures being I(1). The fact that the cash prices have unit root suggests the futures should as well, given the no-arbitrage condition and market efficiency condition assumed in the literature (CLS (2004)). Therefore, all prices are assumed to suffer from unit root.

\section{[INSERT TABLE 3 HERE]}

\footnotetext{
${ }^{2}$ A range of possible break points were selected including the minimum, mean, and maximum. All three of these were tested with their respective lambda statistic and all proved to change the results very little. Also, the test statistics were calibrated as needed to more appropriately capture a break that falls between the values offered in the study. These were altered approximately 0.75 for each incremental move away from the lambda statistic to produce more reliable estimates.
} 
Given that all the variables appear to be integrated of order 1, the optimal hedge ratios are calculated for 9 hedging horizons ranging from one day, one week to eight weeks. The results are reported in Table 4 . All the estimates in Table 4 prove to be significant at the $1 \%$ level of significance. Estimation of the ratios is performed using simple OLS from equation (4). The variables are differenced to account for unit root and autocorrelation. Ultimately, all the optimal hedge ratios do not converge towards one across greater hedging horizons. Many of them do appear to fluctuate across the horizons but each of the markets exhibit a distinct trend (except aluminum) towards a value greater than one. The very short horizon (one-day) optimal hedge ratios are all less than 0.65 but, as soon as the differentiation frequency is increased to 1-week, the optimal ratio increase to a range from 0.83 (Tin) to 0.99 (Nickel). The ratio at the 4-week horizon are all greater than 1, ranging from 1.00 (Aluminum and Copper) to 1.11 (Nickel). At the longest time horizon we study, the optimal ratios range from 1.00 (Aluminum) to 1.17 (Nickel). Overall, the average (median) 8-week hedging horizon across the six metals is roughly 1.074 (1.066). Empirically, this means that the trader should be hedged $7.4 \%$ above the respective spot position. This finding is contrary to the findings of CLS and Geppert who both found that the optimal hedge ratio converges to one across greater time horizons. Table 4 suggests that, in general, the proportion of spot positions to be covered by opposite positions on futures markets is greater than one. This finding is of importance, but at this point, should be considered preliminary since the $\mathrm{I}(1)$ prices in this study are assumed to trend together over time which can lead to misleading results in an OLS regression (Chowdhury (1991)). 
[INSERT TABLE 4 HERE]

Given that all the variables in the model contain unit root, it is anticipated that all the relationships between spot and futures prices share a long-run stochastic trend. Table 5 verifies that each of the 6 markets studied do share a mean-reverting relationship, as in each case the test statistic is greater than the upper I(1) bound found in the Pesaran study. The test employed here has two variables (k), an intercept, and no trend. The $10 \%$ critical value is 4.14 in this case, which means that for the series to be cointegrated the test statistic must be greater than the 4.14 test statistic. The use of this test improves on several earlier studies that used the Engle-Granger method. Using this test takes advantage of the minimum variance criterion used in the test that is also used in the risk management application of this study (Alexander (1999)). These tests were reinforced with the Engle-Granger test that provided the same conclusions as the Pesaran approach.

\section{[INSERT TABLE 5 HERE]}

Having confirmed that all the variables within each respective market are cointegrated, the associated joint estimation that ties this long-run co-movement together is performed. The estimation approach is CLS's which jointly estimates the long-run and short-run hedge ratios. Table 6 presents the result from this approach and it is apparent that the results are very similar to that of the previous short-run estimation. This estimation, which correctly includes the long-run properties of the cash-futures 
relationship, should account for the concerns associated with the estimation of equation (4). Correcting for cointegration issues, the results in Table 6 tend to bear out that the naïve estimation of equation (4) leads to over-estimation of the optimal hedge ratio. At the 8-week horizon, the optimal hedge ratio in Table 6 is lower than that in Table 4 for 4 of the 6 metal markets, namely aluminum, lead, nickel and zinc. Nonetheless, the results in Table 6 confirm that, after controlling for cointegration issues, the hedgers should have been overhedged to minimize the variance of their cash position. Namely, market participants should, across the six metals on average, overhedge by $6.7 \%$ at the 8 -week hedging horizon. One may question whether $7.4 \%$ and $6.7 \%$ are really different from one another. However, using the hypothetical aluminum requirement of 100,000 MT used in Section III as a benchmark, the two different hedge ratios account for a $\$ 1.9 \mathrm{M}$ difference when employing the two hedge ratio values. Any firm would be more than glad to add this additional cost avoidance to their portfolio. Again, these findings are indicative of the volatile commodity landscape that has taken form over the recent years.

\section{[INSERT TABLE 6 HERE]}

The study by CLS points out that the short-run hedge ratio should approach the long-run hedge in this joint estimation. Table 6 provides confirmation of this fact. First, as one can anticipate, at the one day horizon, the two estimates are very different. The average value of the percentage difference between the two estimates, measured as (Short-run ratio - Long-run ratio) / Long-run ratio, is a high $-41 \%$. At the one-week horizon, the difference is already greatly reduced to $-7.6 \%$ and is further reduced at the 2 - 
week horizon to $-2.7 \%$. Aggregating all other horizons reported in Table 6 , the difference narrows to an average $0.1 \%$ confirming the convergence but we should note that the sign of this difference is not consistent either across horizon or across markets.

Finally, Table 7 presents the findings of how effective these optimal hedge ratios would be in a portfolio consisting of cash and futures positions. All the metals are considered in this example to thoroughly evaluate the effectiveness of the hedges. All the values appear to exhibit a common trend towards the mid-90\% across the hedging horizons. The hedging effectiveness value represents the percentage reduction in variance over and beyond a portfolio unhedged. It is evident that these optimal hedge ratios are useful in minimizing variance but even more important, the hedges improve across the time horizons. Namely, a hedge may be more favorable as the hedging horizon is lengthened given the nature of price discovery in the spot and futures relationship.

\section{[INSERT TABLE 7 HERE]}

A viable question in commodity purchasing departments is: how far out a company should hedge given the nature of the commodity landscape? The empirical evidence contained in this study indicates that, in general, a longer hedging horizon may help mitigate the risk in the spot market. The results provided in Table 7 indicate that the optimal hedging horizon should be at 8 -week or the longest hedging horizon considered in this study. This statement is not saying that the 8 week effectiveness value is always greatest at this horizon, as in the case of aluminum the 6-week horizon is preferred to the 8-week horizon. Rather, it is evident that these values are generally asymptotically 
improving across the horizons and therefore, it is inferred that this would also occur across a broader dataset. A longer hedging horizon is the course of strategy advocated in this study.

\section{CONCLUSIONS}

This study investigates the optimal hedge ratio and hedging effectiveness for six base metals markets. After applying careful econometrics methods, we first document that the short-run optimal hedging ratio is increasing in hedging horizon. If a corporate hedger is attenuating demand risks for his company with a longer time-frame in the futures market, he should increase his exposure to the futures market as his hedging horizon lengthens. Second, we show that the optimal hedging ratio, contrary to results in other markets, does not converge to the naïve ratio of 1 for our markets over our timeperiod over longer time horizons. We document that the appropriate position a hedger should take is to over-hedge by over 5\% in order to best minimize price impacts. Finally, we find that hedging effectiveness for the optimal hedging ratios we computed in an outof-sample methodology is very high in the mid-90's in percentage terms. In other words, implementing a hedge with the hedge ratios we determined would eliminate over $90 \%$ of price uncertainty for large corporation procurement departments. Overall, the best hedging decision for these markets is to hedge long-term at about 6 to 8 weeks with a slightly greater than one hedge ratio. These results are robust to the increased volatility over our data period and are of great interest to many purchasing departments and other commodity hedgers. 


\section{BIBLIOGRAPHY}

Alexander, C. (1999), "Optimal Hedging Using Cointegration”, Philosophical Transactions: Mathematical, Physical and Engineering Sciences, Vol. 357, No. 1758, 2039-2058.

Anderson, Ronald and Jean-Pierre Danthine (1981), "Cross Hedging", The Journal of Political Economy, Vol. 89, No. 6, 1182-1196.

Baillie, Richard and Robert Myers (1990), "Bivariate GARCH Estimation of the Optimal Commodity Futures Hedge”, The Journal of Applied Econometrics, Vol. 6, 109-124.

Benninga, Simon, Rafael Eldor, and Itzhak Zilcha (1984), “The Optimal Hedge Ratio in Unbiased Futures Markets”, The Journal of Futures Markets, Vol. 4, No. 2, 155-159.

Chen, Sheng-Syan, Cheng-Few Lee, and Keshab Shrestha (2004), “An Empirical Analysis of the Relationship Between the Hedge Ratio and Hedging Horizon: A Simultaneous Estimation of the Short- and Long-Run Hedge Ratios", The Journal of Futures Markets, Vol. 24, No. 4, 359-386.

Chowdhury, Abdur (1991), "Futures Market Efficiency: Evidence from Cointegration Tests", The Journal of Futures Markets, Vol. 11, No. 5, 577-589.

Corporate Executive Board (2003), "Managing Procurement Risk: Assessment, Monitoring, and Mitigation”, Procurement Strategy Council Teleconference.

Dickson, Duane, Jim Manocchi, and Sanjay Agarwal (2006), "Commodity Management: Profiting from Volatility", Chemical Week, July 2006.

Ederington, Louis (1979), "The Hedging Performance of the New Futures Markets", The Journal of Finance, Vol. 34, No. 1, 157-170.

Fletcher, Lehman and Ronald Ward (1971), "From Hedging to Pure Speculation: A Micro Model of Optimal Futures and Cash Market Positions", American Journal of Agricultural Economics, Vol. 53, No. 1, 71-78.

Freed, Dan (2007), “Commodity Desk Still Staffing Up: Fear of Price Declines Can't Dampen Enthusiasm for Asset Class”, The Investment Dealers' Digest, January 29, 2007, 1 .

Froot, Kenneth, David Scharfstein, and Jeremy Stein (1993), "Risk Management: Coordinating Corporate Investment and Financing Policies", The Journal of Finance, Vol. 48, No. 5, 1629-1658. 
Geppert, John (1995), “A Statistical Model for the Relationship between Futures Contract Hedging Effectiveness and Investment Horizon Length", The Journal of Futures Markets, Vol. 15, No. 5, 507-536.

Hansen, Morten and Nitin Nohria (2004), "How to Build Collaborative Advantage", MIT Sloan Management Review, Vol. 46, No. 1, 22-30

Holz, Rebecca (2006), “Trading Volume”, Futures Industry, September - October 2006, $10-14$.

Introduction to the Futures and Options Markets (1998), "Institute for Financial Markets", accessed August 29, 2006, http://www.theifm.org/tutorial/contracts.htm

Koppenhaver, Gary and Steven Swidler (1996), "Corporate Hedging and Input Price Risk”, Managerial and Decision Economics, Vol. 17, No. 1, 83-92.

Lien, Donald and Xiangdong Luo (1993), "Estimating Multiperiod Hedge Ratios in Cointegrated Markets", The Journal of Futures Markets, Vol. 13, No. 8, 909-920.

Myers, Robert and Stanley Thompson (1989), "Generalized Optimal Hedge Ratio Estimation”, American Journal of Agricultural Economics, Vol. 71, No. 4, 858-868.

Perron, Pierre (1989), "The Great Crash, the Oil Price Shock, and the Unit Root Hypothesis", Econometrica, Vol. 57, No. 6, 1361-1401.

Pesaran, M. Hashem, Youngcheol Shin, and Richard Smith (2001), "Bounds Testing Approaches to the Analysis of Level Relationships", Journal of Applied Econometrics, Vol. 16, 289-326.

Pesaran, M. Hashem (1997), "The Role of Economic Theory in Modeling the Long Run", Economic Journal, Vol. 107, No. 440, 178-191.

Stock, James and Mark Watson (1988), "Testing for Common Trends", Journal of the American Statistical Association, Vol. 83, No. 404, 1097-1107. 


\section{FIGURE 1}

Figure 1 graphs in two panels the complete time series of data used in the study. In each panel, using the same scale, we highlight the dramatic price increase experienced by the metals markets over the study period. From these representations, we determine break points which are reported in Table 2.
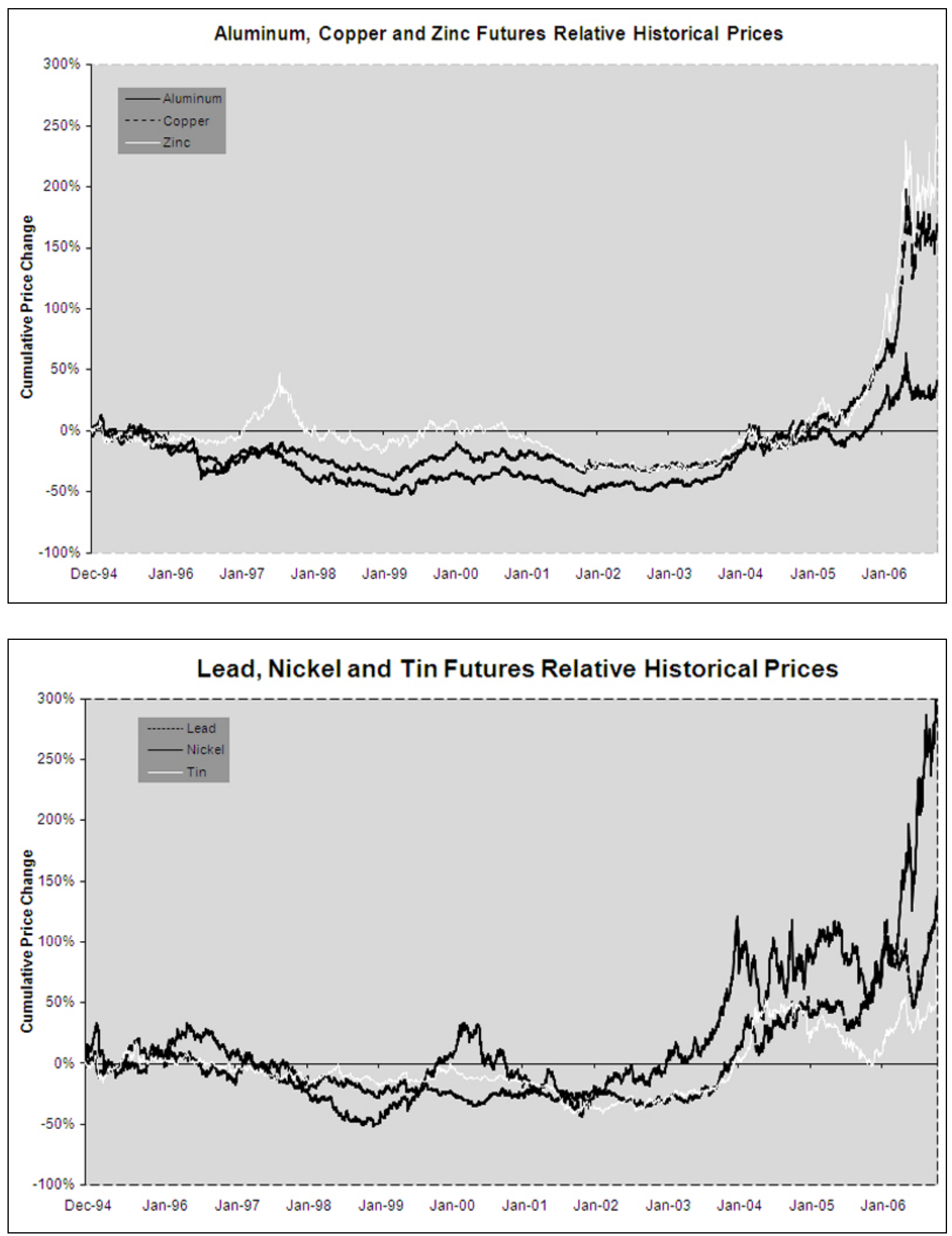


\section{TABLE 1 - Data Description}

Table 1 reports the time period and frequency of the data used in our empirical determination of the optimal hedge ratio and optimal hedging horizon. All prices are prices from the London Metal Exchange (LME). The futures price information is obtained from Futuresource, a platform relaying the LME data, and represents the near-by futures contract. The cash prices are related to the second bell close on the LME.

\begin{tabular}{|r|c|c|c|}
\hline Base Metal & Data Sample Range & Frequency & Observations \\
\hline Aluminum & July 8,1998 - October 19,2006 & Daily & 2068 \\
Copper & July 8,1998-October 19,2006 & Daily & 2066 \\
Lead & July 8,1998-October 19,2006 & Daily & 2068 \\
Nickel & July 8,1998-October 19,2006 & Daily & 2063 \\
Tin & July 15,1998-October 19,2006 & Daily & 2064 \\
Zinc & July 15,1998-October 19,2006 & Daily & 2058 \\
\hline
\end{tabular}




\section{TABLE 2 - Descriptive Statistics}

Table 2 reports sample descriptive statistics for the cash prices for all 6 metal markets investigated in the study. Over the sample period, each of these markets exhibited a large change in both price level and volatility level. The table reports the mean, maximum, minimum and the standard deviation of prices for each market for the two distinct periods: before the price level change break and after the price level change break. The break points are determined visually from the historical price charts and are reported in the table below. In addition, the table reports the ratio of volatility to level of prices $(\sigma / \mu)$ before and after the break to confirm that the break represents both a change in level and a change in volatility in prices.

\begin{tabular}{|c|c|c|c|}
\hline Metal & Before Break & After Break & \% Increase \\
\hline ALUMINUM & Break Point Date & \multicolumn{2}{|c|}{ 17-Mar-05 } \\
\hline \multirow{5}{*}{$\begin{array}{l}\text { Mean } \\
\text { Standard Dev } \\
\text { Maximum } \\
\text { Minimum } \\
\sigma / \mu\end{array}$} & $\$ \mathbf{\$ 1 , 5 4 0}$ & $\$ 2,169$ & $41 \%$ \\
\hline & $\$ 180$ & $\$ 354$ & $97 \%$ \\
\hline & $\$ 2,186$ & $\$ 3,180$ & $45 \%$ \\
\hline & $\$ 1,161$ & $\$ 1,688$ & $45 \%$ \\
\hline & 0.117 & 0.163 & $40 \%$ \\
\hline COPPER & Break Point Date & \multicolumn{2}{|c|}{ 15-Nov-04 } \\
\hline \multirow{5}{*}{$\begin{array}{l}\text { Mean } \\
\text { Standard Dev } \\
\text { Maximum } \\
\text { Minimum } \\
\sigma / \mu\end{array}$} & $\$ \$ 2,012$ & $\$ 4,770$ & $137 \%$ \\
\hline & $\$ 483$ & $\$ 1,796$ & $272 \%$ \\
\hline & $\$ 3,140$ & $\$ 8,650$ & $175 \%$ \\
\hline & $\$ 1,339$ & $\$ 2,865$ & $114 \%$ \\
\hline & 0.240 & 0.377 & $57 \%$ \\
\hline LEAD & Break Point Date & \multicolumn{2}{|c|}{ 29-Jan-04 } \\
\hline \multirow{5}{*}{$\begin{array}{l}\text { Mean } \\
\text { Standard Dev } \\
\text { Maximum } \\
\text { Minimum } \\
\sigma / \mu\end{array}$} & \begin{tabular}{|l|}
560 \\
\end{tabular} & $\$ 989$ & $77 \%$ \\
\hline & $\$ 106$ & $\$ 165$ & $56 \%$ \\
\hline & $\$ 862$ & $\$ 1,540$ & $79 \%$ \\
\hline & $\$ 415$ & $\$ 693$ & $67 \%$ \\
\hline & 0.189 & 0.167 & $-12 \%$ \\
\hline NICKEL & Break Point Date & \multicolumn{2}{|c|}{ 8-Jan-04 } \\
\hline \multirow{5}{*}{$\begin{array}{l}\text { Mean } \\
\text { Standard Dev } \\
\text { Maximum } \\
\text { Minimum } \\
\sigma / \mu \\
\end{array}$} & \begin{tabular}{|l|}
7,204 \\
\end{tabular} & $\$ 16,126$ & $124 \%$ \\
\hline & $\$ 1,777$ & $\$ 4,442$ & $150 \%$ \\
\hline & $\$ 17,100$ & $\$ 31,900$ & $87 \%$ \\
\hline & $\$ 3,785$ & $\$ 10,550$ & $179 \%$ \\
\hline & 0.247 & 0.275 & $12 \%$ \\
\hline TIN & Break Point Date & \multicolumn{2}{|c|}{ 18-Mar-04 } \\
\hline \multirow{5}{*}{$\begin{array}{l}\text { Mean } \\
\text { Standard Dev } \\
\text { Maximum } \\
\text { Minimum } \\
\sigma / \mu\end{array}$} & $\$ 55,371$ & $\$ 8,095$ & $51 \%$ \\
\hline & $\$ 769$ & $\$ 887$ & $15 \%$ \\
\hline & $\$ 7,795$ & $\$ 11,000$ & $41 \%$ \\
\hline & $\$ 3,638$ & $\$ 6,000$ & $65 \%$ \\
\hline & 0.143 & 0.110 & $-23 \%$ \\
\hline ZINC & Break Point Date & \multicolumn{2}{|c|}{ 17-Mar-05 } \\
\hline \multirow{5}{*}{$\begin{array}{l}\text { Mean } \\
\text { Standard Dev } \\
\text { Maximum } \\
\text { Minimum } \\
\sigma / \mu\end{array}$} & $\$ 1,036$ & $\$ 2,213$ & $114 \%$ \\
\hline & $\$ 162$ & $\$ 894$ & $452 \%$ \\
\hline & $\$ 1,672$ & $\$ 3,960$ & $137 \%$ \\
\hline & $\$ 745$ & $\$ 1,178$ & $58 \%$ \\
\hline & 0.156 & 0.404 & $158 \%$ \\
\hline
\end{tabular}




\section{TABLE 3 - Perron Unit Root Test}

Table 3 reports the results of the Perron Unit Root test performed on both the cash and the futures price time series. The Perron Unit Test allows to determine if the price series is integrated of order 1, I(1). Unit root testing was performed on weekly data. $\lambda$ represents the proportion of the sample at which the break points occurs. The tests are based on Perron (1989) $10 \%$ critical values with both a slope and intercept shift. * denotes an I(1) series or unit root.

\begin{tabular}{|l|c|c|c|c|c|c|c|}
\hline \multicolumn{2}{|c|}{ Variables } & \multicolumn{4}{c|}{ Cash } & \multicolumn{3}{c|}{ Futures } \\
METAL & Sample Frequency & $\lambda$ & Test Statistic & Critical Value & $\lambda$ & Test Statistic & Critical Value \\
\hline ALUMINUM & Weekly (433) & $\mathbf{0 . 8}$ & $\mathbf{- 3 . 3 4 ^ { * }}$ & $\mathbf{- 3 . 6 9}$ & $\mathbf{0 . 8}$ & $\mathbf{- 3 . 5 3 *}$ & $\mathbf{- 3 . 6 9}$ \\
\hline COPPER & Weekly (433) & $\mathbf{0 . 7}$ & $\mathbf{- 2 . 7 7 ^ { * }}$ & $\mathbf{- 3 . 8 6}$ & $\mathbf{0 . 7}$ & $\mathbf{- 2 . 5 1 ^ { * }}$ & $\mathbf{- 3 . 8 6}$ \\
\hline LEAD & Weekly (433) & $\mathbf{0 . 7}$ & $\mathbf{0 . 0 2 ^ { * }}$ & $\mathbf{- 3 . 8 6}$ & $\mathbf{0 . 7}$ & $\mathbf{0 . 0 2} *$ & $\mathbf{- 3 . 8 6}$ \\
\hline NICKEL & Weekly (433) & $\mathbf{0 . 7}$ & $\mathbf{- 0 . 3 8 ^ { * }}$ & $\mathbf{- 3 . 8 6}$ & $\mathbf{0 . 7}$ & $\mathbf{0 . 1 4 ^ { * }}$ & $\mathbf{- 3 . 8 6}$ \\
\hline TIN & Weekly (433) & $\mathbf{0 . 7}$ & $\mathbf{0 . 7 1 *}$ & $\mathbf{- 3 . 8 6}$ & $\mathbf{0 . 7}$ & $\mathbf{- 0 . 6 4}$ & $\mathbf{- 3 . 8 6}$ \\
\hline ZINC & Weekly (433) & $\mathbf{0 . 9}$ & $\mathbf{- 2 . 5 3 ^ { * }}$ & $\mathbf{- 3 . 4 6}$ & $\mathbf{0 . 8}$ & $\mathbf{- 3 . 9 7}$ & $\mathbf{- 3 . 8 6}$ \\
\hline
\end{tabular}




\section{TABLE 4- OLS Minimum Variance Hedge Ratio}

Table 4 reports the empirical results of estimating the optimal minimum variance hedge ratio for each of the six metal markets. The estimation in this table relies on Equation (4):

$$
\left(\mathrm{P}_{1}-\mathrm{P}_{0}\right)=\alpha+\beta\left(\mathrm{F}_{1}-\mathrm{F}_{0}\right)+\varepsilon
$$

where the MV Hedge Ratio reported is the point estimate of $\beta$ in Equation (4) found with an Ordinary Least Squares (OLS) estimation. The table also contains the standard deviation of the estimate and the adjusted $\mathrm{R}$-Square of the OLS regression. The analysis is repeated at different level of differentiation from as short as one day to as long as 8 weeks. Due to data constraint (our time series contains 433 weeks worth of data), we limit our longest hedging horizon to 8 weeks to insure our results remain statistically meaningful.

\begin{tabular}{|c|c|c|c|c|c|c|c|c|c|c|}
\hline METAL & Statistic & $\begin{array}{c}1 \\
\text { Day }\end{array}$ & $\begin{array}{c}1 \\
\text { Week }\end{array}$ & $\begin{array}{c}2 \\
\text { Weeks }\end{array}$ & $\begin{array}{c}3 \\
\text { Weeks }\end{array}$ & $\begin{array}{c}4 \\
\text { Weeks }\end{array}$ & $\begin{array}{c}5 \\
\text { Weeks }\end{array}$ & $\begin{array}{c}6 \\
\text { Weeks }\end{array}$ & $\begin{array}{c}7 \\
\text { Weeks }\end{array}$ & $\begin{array}{c}8 \\
\text { Weeks }\end{array}$ \\
\hline ALUMINUM & $\begin{array}{r}\text { MVHedge Ratio } \\
\text { Std. Deviation } \\
\text { Adj. R-Squared }\end{array}$ & $\begin{array}{c}\mathbf{0 . 4 7 5} \\
(0.020) \\
0.210 \\
\end{array}$ & $\begin{array}{l}\mathbf{0 . 9 0 9} \\
(0.020) \\
0.824 \\
\end{array}$ & $\begin{array}{l}\mathbf{0 . 9 7 3} \\
(0.028) \\
0.853 \\
\end{array}$ & $\begin{array}{l}\mathbf{0 . 9 9 6} \\
(0.028) \\
0.899 \\
\end{array}$ & $\begin{array}{l}\mathbf{1 . 0 0 2} \\
(0.031) \\
0.907 \\
\end{array}$ & $\begin{array}{l}\mathbf{1 . 0 2 0} \\
(0.036) \\
0.903 \\
\end{array}$ & $\begin{array}{l}\mathbf{1 . 0 6 7} \\
(0.031) \\
0.940 \\
\end{array}$ & $\begin{array}{l}\mathbf{1 . 0 5 4} \\
(0.038) \\
0.927 \\
\end{array}$ & $\begin{array}{l}\mathbf{1 . 0 0 6} \\
(0.029) \\
0.959 \\
\end{array}$ \\
\hline COPPER & $\begin{array}{r}\text { MV Hedge Ratio } \\
\text { Std. Deviation } \\
\text { Adj. R-Squared }\end{array}$ & $\begin{array}{c}\mathbf{0 . 3 9 1} \\
-0.019 \\
0.178\end{array}$ & $\begin{array}{r}\mathbf{0 . 8 6 0} \\
-0.021 \\
0.800\end{array}$ & $\begin{array}{l}\mathbf{1 . 0 0 7} \\
-1.027 \\
0.868\end{array}$ & $\begin{array}{c}\mathbf{1 . 0 3 2} \\
-0.015 \\
0.973\end{array}$ & $\begin{array}{c}\mathbf{1 . 0 0 1} \\
-0.020 \\
0.960\end{array}$ & $\begin{array}{c}\mathbf{1 . 0 1 8} \\
-0.025 \\
0.953\end{array}$ & $\begin{array}{c}\mathbf{1 . 0 5 1} \\
-0.016 \\
0.983\end{array}$ & $\begin{array}{c}\mathbf{0 . 9 9 0} \\
-0.014 \\
0.988\end{array}$ & $\begin{array}{c}\mathbf{1 . 0 2 6} \\
-0.016 \\
0.987\end{array}$ \\
\hline LEAD & $\begin{array}{r}\text { MV Hedge Ratio } \\
\text { Std. Deviation } \\
\text { Adj. R-Squared }\end{array}$ & $\begin{array}{r}\mathbf{0 . 6 5 4} \\
-0.023 \\
0.284 \\
\end{array}$ & $\begin{array}{c}\mathbf{0 . 9 5 1} \\
-0.027 \\
0.749\end{array}$ & $\begin{array}{c}\mathbf{1 . 0 2 3} \\
-0.036 \\
0.792 \\
\end{array}$ & $\begin{array}{c}1.022 \\
-0.028 \\
0.904\end{array}$ & $\begin{array}{r}\mathbf{1 . 0 7 5} \\
-0.049 \\
0.820\end{array}$ & $\begin{array}{r}\mathbf{1 . 0 5 5} \\
-0.032 \\
0.930\end{array}$ & $\begin{array}{r}\mathbf{1 . 1 0 0} \\
-0.034 \\
0.938 \\
\end{array}$ & $\begin{array}{c}1.046 \\
-0.034 \\
0.941\end{array}$ & $\begin{array}{r}\mathbf{1 . 1 0 8} \\
-0.032 \\
0.957\end{array}$ \\
\hline NICKEL & $\begin{array}{r}\text { MV Hedge Ratio } \\
\text { Std. Deviation } \\
\text { Adj. R-Squared }\end{array}$ & $\begin{array}{r}\mathbf{0 . 5 2 6} \\
-0.022 \\
0.218 \\
\end{array}$ & $\begin{array}{r}\mathbf{0 . 9 9 2} \\
-0.025 \\
0.788\end{array}$ & $\begin{array}{c}1.103 \\
-0.028 \\
0.879\end{array}$ & $\begin{array}{c}1.074 \\
-0.037 \\
0.853\end{array}$ & $\begin{array}{r}\mathbf{1 . 1 1 6} \\
-0.032 \\
0.920\end{array}$ & $\begin{array}{l}\mathbf{1 . 0 0 2} \\
-0.027 \\
0.944\end{array}$ & $\begin{array}{r}\mathbf{1 . 0 8 4} \\
-0.021 \\
0.975 \\
\end{array}$ & $\begin{array}{c}\mathbf{1 . 0 3 4} \\
-0.047 \\
0.892\end{array}$ & $\begin{array}{r}\mathbf{1 . 1 7 3} \\
-0.044 \\
0.932 \\
\end{array}$ \\
\hline TIN & $\begin{array}{r}\text { MV Hedge Ratio } \\
\text { Std. Deviation } \\
\text { Adj. R-Squared }\end{array}$ & $\begin{array}{r}\mathbf{0 . 4 4 3} \\
-0.021 \\
0.185 \\
\end{array}$ & $\begin{array}{c}\mathbf{0 . 8 3 2} \\
-0.026 \\
0.701\end{array}$ & $\begin{array}{r}\mathbf{0 . 8 7 2} \\
-0.028 \\
0.820 \\
\end{array}$ & $\begin{array}{c}1.004 \\
-0.023 \\
0.903\end{array}$ & $\begin{array}{r}\mathbf{1 . 0 1 2} \\
-0.030 \\
0.915 \\
\end{array}$ & $\begin{array}{r}\mathbf{1 . 0 6 2} \\
-0.043 \\
0.880\end{array}$ & $\begin{array}{r}\mathbf{1 . 0 3 0} \\
-0.028 \\
0.951 \\
\end{array}$ & $\begin{array}{r}\mathbf{1 . 0 4 3} \\
-0.029 \\
0.957\end{array}$ & $\begin{array}{r}1.053 \\
-0.032 \\
0.954 \\
\end{array}$ \\
\hline ZINC & $\begin{array}{r}\text { MV Hedge Ratio } \\
\text { Std. Deviation } \\
\text { Adj. R-Squared }\end{array}$ & $\begin{array}{r}\mathbf{0 . 5 5 4} \\
-0.021 \\
0.255 \\
\end{array}$ & $\begin{array}{c}\mathbf{0 . 9 8 2} \\
-0.020 \\
0.853\end{array}$ & $\begin{array}{r}\mathbf{0 . 9 8 6} \\
-0.025 \\
0.884\end{array}$ & $\begin{array}{c}1.099 \\
-0.023 \\
0.943\end{array}$ & $\begin{array}{c}\mathbf{1 . 0 3 6} \\
-0.024 \\
0.948\end{array}$ & $\begin{array}{c}\mathbf{1 . 0 0 2} \\
-0.016 \\
0.979\end{array}$ & $\begin{array}{r}\mathbf{1 . 0 5 9} \\
-0.024 \\
0.966\end{array}$ & $\begin{array}{c}1.117 \\
-0.017 \\
0.986\end{array}$ & $\begin{array}{c}1.079 \\
-0.014 \\
0.992\end{array}$ \\
\hline
\end{tabular}




\section{TABLE 5 - Pesaran Cointegration Tests}

Table 5 reports the results of test statistics about the cointegration of the data series. Specifically, the Pesaran cointegration test (1997) is run. The test employed has two variables (k), an intercept and no trend. The $10 \%$ critical value is 4.14 in this case. Cointegration was also found to be the case in Engle-Granger tests using ADF and the Engle-Granger test statistics.

\begin{tabular}{|l|c|c|c|c|}
\hline \multicolumn{1}{|c|}{ METAL } & \# of Lags & Beta & F-Statistic & Cointegration \\
\hline \hline ALUMINUM & 5 & 1.02 & 5.06 & $Y E S$ \\
COPPER & 6 & 0.64 & 7.93 & $Y E S$ \\
LEAD & 5 & 0.58 & 9.87 & $Y E S$ \\
NICKEL & 6 & 0.83 & 11.23 & $Y E S$ \\
TIN & 5 & 0.60 & 6.00 & $Y E S$ \\
ZINC & 6 & 0.72 & 12.87 & $Y E S$ \\
\hline
\end{tabular}




\section{TABLE 6 - Joint Estimation of the Short-Run and Long-Run MV Hedge Ratios}

Table 6 reports the empirical results of estimating the optimal minimum variance hedge ratio for each of the six metal markets. The estimation in this table relies on Equation (12):

$$
\left(\mathrm{P}_{1}-\mathrm{P}_{0}\right)=\alpha_{1}+\alpha_{2} \mathrm{P}_{\mathrm{t}-1}+\alpha_{3} \mathrm{~F}_{\mathrm{t}-1}+\beta\left(\mathrm{F}_{1}-\mathrm{F}_{0}\right)+\varepsilon
$$

where the (short-run) MV Hedge Ratio reported is the point estimate of $\beta$ in Equation (12). The table also contains the standard deviation of the estimate and the adjusted R-Square for that estimation. The long-run MV Hedge ratio is computed as $-\alpha_{3} / \alpha_{2}$ and is also reported. The analysis is repeated at different level of differentiation from as short as one day to as long as 8 weeks. Due to data constraint (our time series contains 433 weeks worth of data), we limit our longest hedging horizon to 8 weeks to insure our results remain statistically meaningful.

\begin{tabular}{|c|c|c|c|c|c|c|c|c|c|c|}
\hline METAL & Statistic & $\begin{array}{c}1 \\
\text { Day }\end{array}$ & $\begin{array}{c}1 \\
\text { Week }\end{array}$ & $\begin{array}{c}2 \\
\text { Weeks }\end{array}$ & $\begin{array}{c}3 \\
\text { Weeks }\end{array}$ & $\begin{array}{c}4 \\
\text { Weeks }\end{array}$ & $\begin{array}{c}5 \\
\text { Weeks }\end{array}$ & $\begin{array}{c}6 \\
\text { Weeks }\end{array}$ & $\begin{array}{c}7 \\
\text { Weeks }\end{array}$ & $\begin{array}{c}8 \\
\text { Weeks }\end{array}$ \\
\hline ALUMINUM & $\begin{array}{c}\text { MV Hedge Ratio } \\
\text { Std. Deviation } \\
-\alpha 3 / \alpha 2 \\
\text { Adj. } \text { R-Squared }\end{array}$ & $\begin{array}{c}\mathbf{0 . 6 2 4} \\
(0.021) \\
0.990 \\
0.305\end{array}$ & $\begin{array}{c}\mathbf{0 . 9 4 6} \\
(0.019) \\
0.996 \\
0.859\end{array}$ & $\begin{array}{c}\mathbf{0 . 9 8 1} \\
(0.025) \\
0.992 \\
0.887\end{array}$ & $\begin{array}{c}\mathbf{0 . 9 8 5} \\
(0.025) \\
0.997 \\
0.922\end{array}$ & $\begin{array}{c}\mathbf{0 . 9 8 2} \\
(0.027) \\
0.994 \\
0.935\end{array}$ & $\begin{array}{c}\mathbf{1 . 0 0 9} \\
(0.030) \\
0.995 \\
0.941\end{array}$ & $\begin{array}{c}\mathbf{1 . 0 3 3} \\
(0.031) \\
0.991 \\
0.954\end{array}$ & $\begin{array}{c}\mathbf{1 . 0 1 3} \\
(0.034) \\
1.007 \\
0.954\end{array}$ & $\begin{array}{c}\mathbf{0 . 9 8 7} \\
(0.027) \\
0.983 \\
0.971\end{array}$ \\
\hline COPPER & $\begin{array}{c}\text { MV Hedge Ratio } \\
\text { Std. Deviation } \\
-\alpha 3 / \alpha 2 \\
\text { Adj. } R \text {-Squared }\end{array}$ & $\begin{array}{c}\mathbf{0 . 4 8 7} \\
(0.020) \\
1.017 \\
0.227\end{array}$ & $\begin{array}{c}\mathbf{0 . 9 0 1} \\
(0.020) \\
1.026 \\
0.829\end{array}$ & $\begin{array}{c}\mathbf{1 . 0 2 2} \\
(0.025) \\
1.033 \\
0.894\end{array}$ & $\begin{array}{c}\mathbf{1 . 0 3 6} \\
(0.015) \\
1.045 \\
0.976\end{array}$ & $\begin{array}{c}\mathbf{1 . 0 0 9} \\
(0.020) \\
1.040 \\
0.967\end{array}$ & $\begin{array}{c}\mathbf{1 . 0 4 4} \\
(0.023) \\
1.046 \\
0.966\end{array}$ & $\begin{array}{c}\mathbf{1 . 0 6 3} \\
(0.017) \\
1.061 \\
0.987\end{array}$ & $\begin{array}{c}\mathbf{0 . 9 9 9} \\
(0.014) \\
1.050 \\
0.990\end{array}$ & $\begin{array}{c}\mathbf{1 . 0 4 2} \\
(0.016) \\
1.060 \\
0.990\end{array}$ \\
\hline LEAD & $\begin{array}{c}\text { MV Hedge Ratio } \\
\text { Std. Deviation } \\
-\alpha 3 / \alpha 2 \\
\text { Adj. } R \text {-Squared }\end{array}$ & $\begin{array}{c}\mathbf{0 . 7 1 6} \\
(0.023) \\
1.044 \\
0.335\end{array}$ & $\begin{array}{c}\mathbf{0 . 9 6 7} \\
(0.025) \\
1.053 \\
0.783\end{array}$ & $\begin{array}{c}\mathbf{1 . 0 2 9} \\
(0.033) \\
1.056 \\
0.830\end{array}$ & $\begin{array}{c}\mathbf{1 . 0 1 8} \\
(0.027) \\
1.052 \\
0.918\end{array}$ & $\begin{array}{c}\mathbf{1 . 0 6 3} \\
(0.046) \\
1.064 \\
0.862\end{array}$ & $\begin{array}{c}\mathbf{1 . 0 3 3} \\
(0.031) \\
1.053 \\
0.944\end{array}$ & $\begin{array}{c}\mathbf{1 . 0 7 8} \\
(0.035) \\
1.065 \\
0.949\end{array}$ & $\begin{array}{c}\mathbf{1 . 0 5 9} \\
(0.035) \\
1.065 \\
0.952\end{array}$ & $\begin{array}{c}\mathbf{1 . 1 0 0} \\
(0.035) \\
1.053 \\
0.963\end{array}$ \\
\hline NICKEL & $\begin{array}{c}\text { MV Hedge Ratio } \\
\text { Std. Deviation } \\
-\alpha 3 / \alpha 2 \\
\text { Adj. } R \text {-Squared }\end{array}$ & $\begin{array}{c}\mathbf{0 . 5 9 7} \\
(0.023) \\
1.054 \\
0.262\end{array}$ & $\begin{array}{c}\mathbf{0 . 9 9 6} \\
(0.024) \\
1.063 \\
0.810\end{array}$ & $\begin{array}{c}\mathbf{1 . 0 8 8} \\
(0.027) \\
1.068 \\
0.899\end{array}$ & $\begin{array}{c}\mathbf{1 . 0 5 5} \\
(0.035) \\
1.059 \\
0.889\end{array}$ & $\begin{array}{c}\mathbf{1 . 1 0 9} \\
(0.032) \\
1.072 \\
0.935\end{array}$ & $\begin{array}{c}\mathbf{0 . 9 9 9} \\
(0.028) \\
1.033 \\
0.952\end{array}$ & $\begin{array}{c}\mathbf{1 . 0 5 9} \\
(0.023) \\
1.042 \\
0.979\end{array}$ & $\begin{array}{c}\mathbf{1 . 0 5 1} \\
(0.047) \\
1.069 \\
0.921\end{array}$ & $\begin{array}{c}\mathbf{1 . 1 2 8} \\
(0.048) \\
1.091 \\
0.952\end{array}$ \\
\hline TIN & $\begin{array}{c}\text { MV Hedge Ratio } \\
\text { Std. Deviation } \\
-\alpha 3 / \alpha 2 \\
\text { Adj. } R \text {-Squared }\end{array}$ & $\begin{array}{c}\mathbf{0 . 5 9 6} \\
(0.021) \\
1.027 \\
0.285 \\
\end{array}$ & $\begin{array}{c}\mathbf{0 . 9 0 8} \\
(0.024) \\
1.030 \\
0.768\end{array}$ & $\begin{array}{c}\mathbf{0 . 9 2 6} \\
(0.026) \\
1.030 \\
0.859\end{array}$ & $\begin{array}{c}\mathbf{1 . 0 0 4} \\
(0.024) \\
1.025 \\
0.927\end{array}$ & $\begin{array}{c}\mathbf{1 . 0 0 9} \\
(0.030) \\
1.033 \\
0.939\end{array}$ & $\begin{array}{c}\mathbf{1 . 0 6 6} \\
(0.034) \\
1.038 \\
0.926\end{array}$ & $\begin{array}{c}\mathbf{1 . 0 1 5} \\
(0.025) \\
1.030 \\
0.965\end{array}$ & $\begin{array}{c}\mathbf{1 . 0 4 3} \\
(0.024) \\
1.030 \\
0.971\end{array}$ & $\begin{array}{c}\mathbf{1 . 0 3 3} \\
(0.028) \\
1.024 \\
0.969\end{array}$ \\
\hline ZINC & $\begin{array}{c}\text { MV Hedge Ratio } \\
\text { Std. Deviation } \\
-\alpha 3 / \alpha 2 \\
\text { Adj. } \text { R-Squared }\end{array}$ & $\begin{array}{c}\mathbf{0 . 6 1 7} \\
(0.023) \\
1.032 \\
0.334 \\
\end{array}$ & $\begin{array}{c}\mathbf{0 . 9 9 4} \\
(0.025) \\
1.012 \\
0.912\end{array}$ & $\begin{array}{c}\mathbf{0 . 9 9 3} \\
(0.018) \\
1.029 \\
0.947 \\
\end{array}$ & $\begin{array}{c}\mathbf{1 . 0 5 8} \\
(0.018) \\
1.036 \\
0.966\end{array}$ & $\begin{array}{c}\mathbf{1 . 0 0 2} \\
(0.026) \\
1.032 \\
0.975\end{array}$ & $\begin{array}{c}\mathbf{0 . 9 9 7} \\
(0.019) \\
1.032 \\
0.977\end{array}$ & $\begin{array}{c}\mathbf{1 . 0 7 3} \\
(0.022) \\
1.029 \\
0.991\end{array}$ & $\begin{array}{c}\mathbf{1 . 0 1 5} \\
(0.031) \\
1.031 \\
0.990\end{array}$ & $\begin{array}{c}\mathbf{1 . 1 1 2} \\
(0.038) \\
1.031 \\
0.991\end{array}$ \\
\hline
\end{tabular}




\section{TABLE 7 - Hedging Effectiveness using Out-of-Sample Analysis}

Table 7 reports the empirical results of implementing the optimal long-run MV Hedge Ratio as determined with the technique used in Table 6. However, in order not to resample, we split the sample in two halves. The first half of the data is used to estimate Equation (12) and to determine the optimal long-run MV Hedge Ratio. This optimal Hedge Ratio was then used to put in place a hedged position for the second half of the sample. We keep track of the changes in value of that portfolio defined as Equation (13):

$$
\Delta \mathrm{V}_{\mathrm{h}}=\mathrm{Q}^{*}\left(\Delta \mathrm{P}_{\mathrm{t}}\right)+\mathrm{X}^{*}\left(\Delta \mathrm{F}_{\mathrm{t}}\right)
$$

We use the series of $\Delta \mathrm{V}_{\mathrm{h}}$ to compute the Hedging Effectiveness as defined in Equation (14):

$$
1-\left[\operatorname{Var}\left(\Delta \mathrm{V}_{\mathrm{h}}\right) / \operatorname{Var}\left(\Delta \mathrm{P}_{\mathrm{t}}\right)\right]
$$

The table contains both the estimated optimal Hedge Ratio and the corresponding Hedge Effectiveness

\begin{tabular}{|c|c|c|c|c|c|c|c|c|c|}
\hline METAL & Statistic & $\begin{array}{c}1 \\
\text { Week }\end{array}$ & $\begin{array}{c}2 \\
\text { Weeks }\end{array}$ & $\begin{array}{c}3 \\
\text { Weeks }\end{array}$ & $\begin{array}{c}4 \\
\text { Weeks }\end{array}$ & $\begin{array}{c}5 \\
\text { Weeks }\end{array}$ & $\begin{array}{c}6 \\
\text { Weeks }\end{array}$ & $\begin{array}{c}7 \\
\text { Weeks }\end{array}$ & $\begin{array}{c}8 \\
\text { Weeks }\end{array}$ \\
\hline \multirow[t]{2}{*}{ ALUMINUM } & Hedging Effectiveness & 0.839 & 0.850 & 0.927 & 0.902 & 0.899 & 0.960 & 0.936 & 0.942 \\
\hline & Optimal Hedge Ratio & 0.923 & 1.037 & 0.976 & 1.080 & 1.052 & 1.090 & 1.026 & 1.1066 \\
\hline COPPER & Hedging Effectiveness & 0.747 & 0.773 & 0.844 & 0.887 & 0.842 & 0.932 & 0.924 & 0.962 \\
\hline \multirow[t]{2}{*}{ LEAD } & Hedging Effectiveness & 0.916 & 0.935 & 0.921 & 0.943 & 0.957 & 0.949 & 0.965 & 0.966 \\
\hline & Optimal Hedge Ratio & 0.964 & 1.012 & 1.002 & 1.058 & 1.059 & 1.025 & 1.064 & 1.098 \\
\hline \multirow[t]{2}{*}{ NICKEL } & Hedging Effectiveness & 0.789 & 0.815 & 0.860 & 0.892 & 0.926 & 0.935 & 0.947 & 0.953 \\
\hline & Optimal Hedge Ratio & 0.984 & 1.054 & 1.036 & 1.093 & 1.048 & 1.011 & 1.112 & 1.100 \\
\hline ZINC & Optimal Hedge Ratio & 0.979 & 0.999 & 1.078 & 1.001 & 1.071 & 1.036 & 1.050 & 1.093 \\
\hline
\end{tabular}
achieved. 